\title{
GEOLOGICAL RECONNAISSANCE OF THE SCORESBY SUND FJORD COMPLEX
}

\author{
Niels Henriksen and W. Stuart Watt
}

GGU started work in the Scoresby Sund fjord complex of East Greenland with a reconnaissance expedition for two months in the summer of 1967. The expedition had the aim of sailing throughout the whole fjord complex to study the weather, ice and terrain conditions as well as the geology in the area in preparation for larger scale operations in the forthcoming years. The expedition was based on a cutter that sailed throughout the whole fjord complex, from the gneiss area in the north, to the south where gneisses are overlain by Tertiary basalts.

The crystalline complex

The crystalline complex in the Scoresby Sund area has been visited earlier by members of Danish expeditions to East Greenland and parts of it have been described by among others Wenk $(1956,1961)$, Vogt (1965), and Haller and Kulp (1962).According to these descriptions the crystalline complex is composed of metamorphosed Caledonian deposits together with a reworked Precambrian basement. Only in the south-westernmost corner of the region is part of the Precambrian basement preserved undisturbed in a tectonic window.

From the results of the short reconnaissance expedition this summer it has been possible to distinguish between two significantly different gneiss series in the innermost part of the fjord region. The older series is formed of banded-veined gneisses which contain abundant amphibolitic bands. This series is highly deformed and has large scale, often recumbent, isoclinal folds. The rocks are commonly strongly migmatized and often contain post-migmatitic amphibolitic dykes which are deformed and cut by pegmatites and leucocratic veins. Isolated parts of this older series are found at low levels in the inner part of Nordvestfjord, Flyverfjord, Harefjord and at the entrance to Vestfjord. 


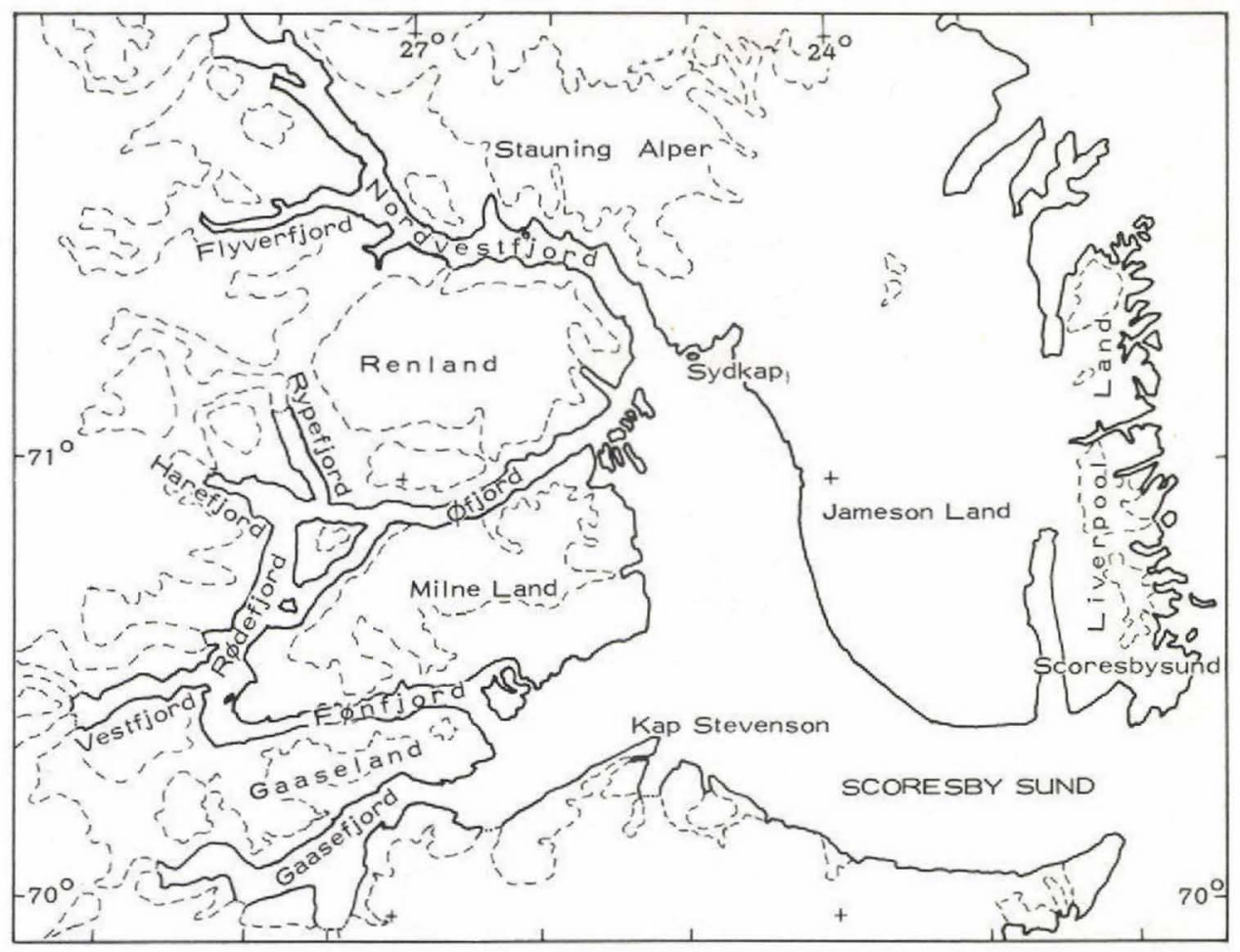

Fig. 4. Map of the Scoresby Sund fjord complex showing the localities mentioned in the text.

The older gneisses are covered by a series of grey and rusty brown, banded, garnet-biotite gneisses. The border between the two series is generally conformable, but a closer examination of some of the localities may reveal the existence of a major geological unconformity. The cover series is commonly only a slightly deformed, flat-lying, monotonous series of several hundred metres thickness. The strongly contrasting styles of tectonic deformation in the two series and the existence of metadykes in the older series indicate that a cover-basement relationship exists here as previously pointed out by earlier writers. 
We have not been able to distinguish between a basement and a younger cover in the outer parts of the inner fjord complex. Here the crystalline rocks are mainly banded gneisses, generally containing garnet and biotite. These gneisses only locally contain amphibolitic bands and inclusions. The gneisses are migmatized and granitized in many places, sometimes resulting in the formation of homogeneous, synkinematic granites. Examples of such granites are abundant in the inner part of $\varnothing$ fjord where huge concordant bodies of foliated garnet-bearing, augen granites exist as sheets and as a core granite in a dome structure. These granites contain numerous ghost remnants of the surrounding banded, garnet-biotite gneiss.

In the outer part of $\varnothing$ fjord the banded and migmatized gneisses are cut by a number of irregular basic dykes and sills which can reach several hundred metres in thickness. The dykes are often strongly sheared and are cut by pegmatites. However, as a sectioned sample taken from the marginal part of a $100 \mathrm{~m}$ wide dyke shows, the dykes are unmetamorphosed biotite gabbro. Another sample of a similar rock, taken from a $1 \mathrm{~m}$ wide dyke cut by pegmatite near Sydkap, shows that this dyke has been only slightly metamorphosed, i.e. the pyroxene is partly uralitized. If these two dykes are compared to similar basic rocks which have been described from the Scoresby Sund region and farther north there are only two possible correlations. They can either be referred to the basic dykes known as discordant amphibolites from the pre-Caledonian basement, or they can correspond to the rocks of the ophiolitic suite described as found in early deposits from the Caledonian geosynclinal stage. If either of these correlations are correct the migmatized banded gneisses surrounding the intrusions ar.e pre-Caledonian and they cannot have been affected by a general regional Caledonian metamorphism but possibly only by local shear deformations and accompanying metamorphic alterations. This implies that considerable parts of the crystalline rocks in the region should be considered as possibly pre-Caledonian and only slightly affected by Caledonian influence.

No remnants of supracrustal geosynclinal rocks have been found during. the reconnaissance trip with the exception of two 
calcareous bands seen in Nordvestfjord. Remnants of very highly metamorphosed rocks have not been identified except in southern Liverpool Land.

The structure in the banded-veined gneisses in the inner fjord region is generally dominated by extensive, flat-lying and gently dipping gneisses. Only a few closures have been identified. This indicates that overfolds, thrusts and nappes probably play an important part in the tectonic pattern.

A number of post-migmatitic, granitic bodies exist on the north and south sides of the outer parts of Nordvestfjord and in $\emptyset_{\text {fjord. }}$ These granites vary from completely homogeneous to striped and banded types. They often contain ghost gneissic remnants and their boundaries to the surrounding gneisses are sometimes sharp and sometimes gradational with intensity of granitization increasing gradually over a long distance towards the granite. One of these bodies, which is found on the north side of Nordvestfjord, is composite and formed by older sheets of synkinematic, garnet-biotite, augen granite and later sheets of a fine-grained, leucocratic, garnet-biotite granite. Another granite body on the south side of the fjord is quite different being a homogeneous, biotite-amphibole granite.

The surroundings of these post-migmatitic granites are often cut by granitic veins and pegmatites, and it is possible that the leucocratic veins found in the basic dykes mentioned earlier are associated with these granites, which could be of Caledonian age.

\section{Jameson Land and Liverpool Land}

The Palaeozoic and Mesozoic rocks in the Jameson Land area were not investigated. In the crystalline rocks of Liverpool Land (see Kranck, 1935) excursions were only made in the immediate vicinity of Scoresbysund town.

\section{R $\phi$ de $\phi$ conglomerate}

The western sides of Rypefjord and R $\phi$ defjord, $R \phi d e \phi$ and parts of Stor $\phi$ consist of a down-faulted wedge of red conglomerate. 
The conglomerate has been described by Bütler (1957) who attributed a Permian age to it (Bütler, 1961). No additional observations were made this summer.

\section{Tertiary basalts}

Tertiary basalts described earlier by Wenk (1961) occur in the southern part of the fjord complex overlying the crystalline gneisses. Horizontal flows have been poured out onto a regular peneplained surface which dips gently to the south-east. Only very occasionally are there traces of relief on the pre-basaltic surface. Individual flows can be traced for many kilometres gradually thinning out with later flows overstepping the earlier to the north and west. At the outer parts of the south coast of Gaasefjord the basalts descend to sea level while on the northern tops of Milne Land the basalts only occur from about $2000 \mathrm{~m}$ upwards. Westwards the base of the basalts ascends less rapidly than northwards, reaching $1400 \mathrm{~m} 15 \mathrm{~km}$ west of the head of Gaasefjord. The highest basalt peaks seen through the binoculars occur on the northern edge of the Geikie Plateau due south of Kap Stevenson. As far as could be seen the basalt flows are essentially horizontal though locally whole mountains have an eastward tilt of $1 / 2$ to $4^{\circ}$ while others tilt $4^{\circ}$ to the south. On the assumption that the basalt flows are near horizontal it is suggested that the exposed basalt succession in the Scoresby Sund area has a thickness in the order of $2000 \mathrm{~m}$.

Material collected in the lower scree slopes on the basalt shows that porphyritic and non-porphyritic basalts are abundant both with and without vesicles filled with zeolites and chalcedony.

Few dykes were seen in the fjord complex and none in the basalt area. Sills are found in the sedimentary rocks near Kap Hope where they are locally abundant. At Sydkap there is a $15 \mathrm{~m}$ wide eastwest trending dyke, and a single dyke of about the same width was traced for many kilometres in a south-west direction across Renland and western Milne Land. 
Quaternary and glacial geology

A raised marine beach was seen on the west side of Rypefjord. The beach deposits consist of layered silts containing shell fragments of Mya truncata and Macoma calcarea. Material was collected for radio-carbon dating so that comparisons can be made to raised beach deposits on the west coast of Greenland.

The positions of glaciers were checked against air photographs taken in 1950. In all but one of the glaciers that could be checked at the fjord coasts there has been no noticeable change in 17 years. The one exception is in the bay to the east of Nordbugt in Nordvestfjord where a glacier has advanced about 7 kilometres and now enters the sea.

References

Bütler, H. (1957) Beobachtungen an der Hauptbruchzone der Küste von Zentral-Ostgrönland. Medd. Grфnland, Bd. 160, Nr. 1.

Bütler, H. (1961) Continental Carboniferous and Lower Permian in central East Greenland. In Raasch, G.O. (edit.) Geology of the Arctic, Vol. 1, 205-213. Univ。 of Toronto Press.

Haller, J. (in prep.) in Geology of the East Greenland Caledonides. New York: Wiley.

Haller, J. and Kulp, J.L. (1962) Absolute age determinations in East Greenland. Medd. Grønland, Bd. 171, Nr. 1.

Kranck, E.H. (1935) On the crystalline complex of Liverpool Land. Medd. Grфnland, Bd. 95, Nr. 7.

Vogt, P. (1965) Zur Geologie von Südwest-Hinks Land (Ostgrönland $\left.71^{\circ} 30^{\prime} \mathrm{N}\right)$. Medd. Grфnland, Bd. 154, Nr. 5.

Wenk, E. (1956) Alpines und ostgrönländisch-kaledonisches Kristallin, ein tektonisch-petrogenetischer Vergleich. Verh. naturf. Ges. Basel, Bd. 67, 75-102。

Wenk, E。 (1961) On the crystalline basement and the basal part of the pre-Cambrian Eleonore Bay group in the southwestern part of Scoresby Sund. Medd. Grфnland, Bd. 168, Nr. 1. 